NBER WORKING PAPER SERIES

ADJUSTMENT IN THE WORLD ECONOMY

Paul Krugman

Working Paper No. 2424

NATIONAL BUREAU OF ECONOMIC RESEARCH

1050 Massachusetts Avenue

Cambridge, MA 02138

October 1987

This paper was prepared for the Fighteenth Plenary Meeting of the Group of Thirty, New York, October 1-3, 1987. The research reported here is part of the NBER's research program in International Studies. Any opinions expressed are those of the author and not those of the National Bureau of Economic Research. 


\section{Adjustment in the World Economy}

\section{$\underline{\text { ABSTRACT }}$}

There is a widespread view that world payments inbajances can be remedied through increased demand in surplus countries and reduced demand in deficit countries, without any need for real eschange rate changes. In fact shifte in demand and real exchange rate adjustment are necessary complements, not substitutes.

The essential reason for this complementerity is that a much higher fraction of a marginal dolser of us than of foreign spending falls on us output. As a result, a redistribution of world spending away from the US leads to an excess supply of US goods unless accompanied by a decline in their relative price. Although come economists bel jeve that the integration of world capital marlets somehow eliminates this problem. this is a fallacy that confuses accounting identities with behavior.

The paper also addresses a number of related issues, such as the role of budget deficits in determining domestici demand and the effectiveness of nominal exchange rates changes in produring real depreciation.

Paul Krugman

NBER

1050 Massachusetts Avenue

Cambridge, MA 02138 
There is widespread though not universal agreenent that the large inbalances in industrial-country current accounts that energed in the 1980 s should be narrowed. Anong those who want a reduction of currentaccount inbalances, however, there is considerable disagreement over what medicine will cure the allaent. Now that the dollar has declined to roughly its 1980 effective exchange rate, should we focus on correcting fiscal divergences, while stabilizing currency values? should the dollar be oriven still lower, since its decline so far has had disappointing results in turning trade around? Or should nations focus fiscal and monetary policy on donestic targets, adopting at least for the time being a position of benign neglect toward exchange rates?

Like nost policy debates, the debate over exchange rate policy stems in part from conflicts of interest, in part froe legitimate disagreements over enpirical paraneters. However, it also appears to stem to an important degree fron confusion pure and simple about how the mechanish of international adjustment works. The purpose of this paper is to cut through as auch of this confusion as possible, clearing the way for debate over the truly disputable issues.

The current discussion of the international adjustment mechanisa is an unusually murky one, because it is not a debate between two coherent positions. Instead, what we have is a coherent but not necessarily correctl standard view that is under attack from a number of directions. This standard view holds in brief that (1) current 
account inbalances are the result of divergent fiscal policies; that (2) this fiscal divergence led to current account divergences via a rise in the relative price of US goods and factors of production, i.e., a real appreciation; and that narrowing the imbalances requires both reversal of the fiscal divergence and (3) a nominal depreciation of the dollar against other industrial-country currencies. Challenges to this view either deny that fiscal policy drives the current account, deny that real exchange rates have anything to do with current accounts, or deny that nominal exchange rate novements have anything to do with real exchange rates. These challenges to the standard view do not add up to a coherent alternative; indeed, some of them are mutually contradictory. That is why attempts to squeeze the debate into a Keynesian-monetarist or supply-side/demand-side mold orily add to the confusion.

The paper is in five parts. The first part elaborates on the standard view of the sources of and cure for current account imbalances, and suggests that challenges to this view can be viewed as originating in negative answers to any one of three key questions that the standard view answers in the affirmative. The second part examines the rationale and empirical evidence bearing on the question, does fiscal policy orive the current account? The third part similarly evaluates the proposition that real exchange rate changes area necessary part of balance of payments adjustment, and the counterargument that in the modern integrated world economy this linkage is gone. The fourth part asks whether the orthodox vien that real 
exchange rate changes are most easily achieved through nominal exchange rate adjustment is valid. A final part oraws the argunents together for an assessment of what we know about the international adjustment mechanism, and what our knowledge says about policy.

To preview the conclusions: the weakest link in the standard view is actually the part that has achieved the most public acceptance: the link from budget imbalances to trade imbalances. While a plausible case for this link can be made, there is enough contrary evidence to give us pause. On the other hand, challenges to other parts of the standard view are as close as any position in economic debate can be to being just plain wrong. The view that real exchange rates have nothing to do with trade balances is, in the form in which it is often stated, a confusion between accounting identities and behavior. There are certain cases in which in principle balance of payments adjustment need not be accompanied by relative price changes, but these cases can be empirically rejected. Similarly, the view that relative price changes would not be facilitated by nominal exchange rate adjustment is often stated in a way that misstates the issue, and a logically coherent statement of the view can be rejected on the basis of the evidence.

THE STANDARD VIEW OF THE ADJUSTMENT MECHANISM 
The standard view of the source of the current account imbalances of the 1980 s takes as its starting point the famous identity

$$
S-I=Y-E=X-M
$$

where $S, I$ are national savings and investment; $Y, E$ national income and expenditure; and $x, M$ national exports and imports of goods and services. An external deficit must have as its counterpart an excess of donestic investment over domestic savings, which makes it natural to look for the sources of a deficit in an autononous change in the national savings rate. The identity nay be further rewritten as

$$
s_{p}+s_{0}-I=X-M
$$

where $S_{p}, S_{0}$ are private and government savings respectively. This immediately suggests how the budget deficit gets into the story. A rise in the budget deficit -- that is, a fall in government saving -nust, unless offset by a rise in private saving, be reflected either in a decline in investaent or a rise in the external deficit. It seems plausible to expect the external deficit to bear part of the burden, so a budget deficit can lead to a trade deficit. While an economy must respect accounting identities, however, looking at these identities can never be the fuld analysis; we nust ask how the accounting identity is translated into incentives that affect individual behavior. The standard view of how a budget deficit 
translates into a trade deficit emphasizes the channel that runs through interest rates and the exchange rate. This view was nost influentially exposited by Martin Feldstein during his tenure as Chairman of the US Council of Economic Advisers'. Subsequent expositions, such as that of Branson (1985), have refined the analysis, but not changed the essential character of the story. In the standard view, a budget deficit is not offset by an increase in private saving. Instead, it leads to a reduction in agregate national saving relative to investment demand. This fall in saving leads to a rise in the real interest rate. The rise in the real interest rate, in turn, by aking clains on the deficit country attractive to foreign investors, leads to a rise in the real exchange rate. With home production more expensive relative to foreign, imports rise and exports fall, leading to an external deficit. The counterpart of this external deficit is a capital inflow that fills the gap between domestic investment and saving.

This standard analysis has achieved remarkably broad acceptance. It was also remarakably successful at accounting for us external economic developments up until about two years ago. Table 1, abstracting from the intervening business cycles, shows how the savings-investment identity held in 1979 and 1985 . The sharp decline in government saving was essentially matched one-for-one by a decline in national savings; the decline in national savings was priadily reflected in a rise in the external deficit rather than in domestic crowding out; the external deficit was accompanied by and therefore 


\section{$-6-$}

presumably largely caused by a huge real appreciation of the dollar, and a sharp rise in US real interest rates was in turn associated with this rise.

The match between theory and experience seemed almost too good to be true, and since 1985 several puzzling developments have spoiled the perfection of the picture. As Table 2 shows, since early 1985 the US exchange rate has fallen sharply, to roughly its pre-Reagan level, and the real interest rate has also fallen considerably. These changes have taken place with little change either in the presumed source of the original disequidibrium, the us budget deficit, or in the external deficit itself. As the predictive power of the standard view has seened to erode, advocates of alternative views have becone increasingly vocal. However, the challenges cone from several different and often contradictory directions, so the net effect of the discussion has been confusing to day audiences and even to many professionals. To clarify this discussion, we need to systematize challenges to the standard view around several key questions.

\section{Key questions about the standard view}

The standard view explains the US external deficit as the result of a budget deficit that operated through a real appreciation, effected by a nominal exchange rate change. Challenges to this view question one or more of the links in this process. Thus the debate over the international adjustment process is really three debates, over three separate questions. 
1. Does fiscal policy drive the current account? While the budget identity linking savings, investment, and the external balance cannot be denied, a decline in government savings need not always be reflected in a corresponding change in the current account. One influential school of thought holds that changes in government saving will be offset by equal and opposite changes in private saving. On this view, national savings fell for reasons independent of the budget deficit. An alternative view -- backed by considerable albeit controversial evidence - holds that the normal effect of a change in national savings is primarily a change in national investment, not a change in the external deficit, so that the apparent one-for-one effect in the first half of the 1980 s was an aberration that needsa special explanation. Finally, some commentators have blamed both the decline in us national savings and the external deficit on tight monetary rather than loose fiscal policy.

2. Does the real exchange rate have anything to do with the trade balance? There is a widespread though not formalized view among policymakers that fiscal policy affects the trade deficit directly, rather than through the channel of real exchange rate changes. Indeed, this view often stands feldstein on his head; where the standard view holds that the us budget deficit caused the strong dollar and hence the trade deficit, one often now hears the view that correction of the US budget deficit is an alternative to further dollar decline. This 
practical men's view overlaps at its edges with two quite distinct alternative views, one that sees faster growth in export markets as the only cure for the trade deficit, and another that denies any need for relative price adjustment as a counterpart to trade adjustment.

3. Does nominal exchange rate adjustment help smooth the path of real adjustment? In a world of perfectly flexible prices, nominal exchange rate changes could neither produce nor facilitate changes in relative goods prices, and thus could have no role in the international adjustment mechanism. The apparent lack of real effects from the dollar's depreciation so far has led monetarist advocates of fixed exchange rates to reemphasize the neutrality of aoney and thus the uselessness of exchange rate changes.

It should be clear even from this brief presentation that the various critiques of the standard view do not add up to a common alternative vision. Clearly the right way to proceed is to address each of the individual questions separately, and then try to draw together what we have learned.

DOES FISCAL POLICY DRIVE THE CURRENT ACCOUNT?

Challenges to the presumed role of the Us internal deficit in causing its external deficit are not central to the curpent debate, 
where the challenges to the standard view mostly go the other way -that is, the budget deficit is given a direct role in causing the trade deficit, independent of the exchange rate. However, criticism of the emphasis on the budget deficit has been a steady rumble since 1982, and adds to the atmosphere of uncertainty about how the international adjstment mechanism works. Thus it is important to be clear about the valid grounds for questioning the conventional view, as expressed by Branson's (1985) often cited remark that "the budget deficit did it!".

One challenge here comes from the supply-side/new classical canp, the other from a more traditional viewpoint that questions the closeness of world capital market integration. He consider each in turn.

Do budget deficits affect national savings?

An extensive debate within the economics profession has swirled around the issue of whether government deficits reduce the national savings rate. This debate is far too elaborate to sumarize here; however, the key issues are fairly simple. Against the prima facie case that government dissaving reduces national saving, an influential "ficardian" view argues that government deficits will be offset by increases in private saving. Suppose that the government cuts taxes without any prospect of future reductions in spending. Then households stould know that in the future the government will have to raise taxes 
again, both to restore the original cuts and to service the increase in its debt. In present value the total expected tax liabilities of the private sector will not have changed; thus the private sector will not increase its consumption, i.e., all of the tax cut will be saved.

The theoretical rejoinder to this argument has several strands. First, some of the tax liability resulting from a temporary tax cut will fall on unborn generations; those currently consuming will therefore experience some reduction in their lifetime tax burden. Second, some households may be liquidity constrained: unable to borrow at the same rate at which they can lend, they prefer a marginal dollar of consumption to a farginal dollar of saving, but are not willing to borrow to spend more than their income. For these households an increase in current income will be spent even if the present value of their lifetime income has not changed. Third, the assertion that tax cuts will be fully saved requires a high degree of sophistication on the part of all households; they must understand the future tax inplications of the current budget. If a sizeable fraction of householos behaves in a less sophisticated way, using some rule of thumb rather than a careful calculation of future government fiscal prospects, much of a tax cut will similarly be spent rather than saved.

The facts of the 1980 sertainly do not provide any support to the Ricardian view; as Table l showed, the US fiscal deficit was reflected fully in a decline in national savings, with no offset from the private sector. This could, of course, be a coincidence; national 
savings might have fallen for other reasons, such as expectations about future cuts in government spending on goods and services or a future surge in productivity and output. I find such explanations widdy unconvincing, and the continuing popularity of the Ricardian view a triumph of theoretical nicety lof a kind that happens to serve a political purpose as welll over both macroeconomic evidence and any plausible description of individual behavior. However, the Ricardian challenge need not occupy much space in this paper, because it is not, as we have noted, central to the international debate.

\section{National savings and the current account}

Whether or not the budget deficit is responsible for the fall in the US national savings rate, there is a legitimate question over whether the equal and opposite movement of US savings and the current account was a normal occurrence, and whether a reversal of the budget deficit should be expected to lead to an unwinding of the trade deficit. Changes in budget deficits can in principle be reflected in changes in domestic investaent rather than in changes in the external account; was it just chance that the Us budget deficit spilled over entirely into the trade deficit? There are several pieces of evidence that might lead one to suspect this.

First, even with perfect capital mobility one should not expect the us budget deficit to crowd out only the trade balance, with no effect on domestic investment. The US is roughly a third of the world 
market economy, so that even in a world in which crowding out is completely global we would expect us investant to absorb about onethird of the fall in national savings, with the external balance absorbing the other two-thirds. In fact much of the world is not open to free capital mobility, so that the external side should absorb less of the deficit. Furthermore, if the appreciation of the dollar is perceived as temporary, it must be sustained by a rise in us real interest rates relative to those abroad; this further concentrates the crowding out on US rather than foreign investment la point made by Frankel (1986)). A back-of-the envelope calculation suggests that something less than half of a change in the us budget deficit should be reflected in the trade balance, and that correspondingly something more than half should be reflected in domestic crowding out (Krugman 1985b).

To explain why virtually all of the deficit was reflected in the external balance, it is necessary to invoke special factors. The effect of US fiscal expansion on the current account was reinforced by nearly equal fiscal contraction in the rest of the OECD (see Blanchard and summers 1984). There may have been an increase in investment demand in the Us as a result of tax cuts and increased optimism. Finally, "safe haven" notivations may have helped push the dollar up. While these additional factors are plausible and do not contradict the basic cenventional view about the way the world works, they do indicate that the perfect correlation between budget and external deficits was indeed too good to be true, and in part a coincidence. 
A deper criticism of the fiscal-external link is that the apparent link for the US in the 1980 s is pretty much unique for industrial countries. Historically, the link between national savings rates and the current account has been at best weak, and the link between national budget positions and the current account virtually nonexistent.

Feldstein and Horioka (1980) showed that there was little correlation between the national savings rates of OECD countries and their current accounts -- or, equivalently, that differences in savings rates seem to have been reflected prinarily in differences in investment. While these results have been extensively critiqued and elaborated (see Frankel 1986), the basic point still stands: the cross-section evidence suggests that capital mobility anong industrial countries is fairly linited. As for the link between budgets and trade, the cross-sectional evidence is not present at all: Japan during the first half of the 1980 s combined the largest current account surplus of the 67 countries with the largest inflation-andunemployment corrected budget deficits (see Gordon 1986).

Again, this cross-sectional evidence can be rationalized. High savings rates and high investment rates might arise from the same causes; further, since saving is measured by investment plus external balance, a bias in the measurment of investment would weaken the apparent correlation between saving and the external balance. However, it must be recognized that the assumption that capital markets are virtually perfectly integrated, which has become conventional wisdon 
in much discussion of international issues, is a view maintained in the face of substantial contrary evidence rather than an established fact.

\section{Did monetary policy do it?}

Some supply-side defenders of the US tax cuts of 1981, such as Roberts (1987), argue that the US current account deficit is the result, not of the fiscal deficit, but of excessively tight monetary policy. This argument can actually be rationalized within a perfectly standard demand-side nacroeconomic view². In the standard MundellFleming model with high capital mobility and sticky prices, a monetary contraction will lead to a real appreciation and a trade deficit. The savings-investment identity will hold because the fall in net exports produces a contraction of national income, leading to a fall in both government revenues and private income; hence both private and government savings fall.

Many economists would agree that this is a good story for the early stages of the rising dollar and the emerging external imbalances in 1981 and 1982. However, it is a difficult story to maintain for the persisting imbalances of 1984 and after. The reason is that an unavoidable side implication of the story is that the country experiencing a monetary contraction must also be experiencing a decline in output -- if not in absolute terms, at least relative to the rest of the world. This flies in the face of the fact that the 
widening of external imbalances continued during the us recovery of 1982-5, which was dranatically aore rapid than that of other industrial countries and has brought the us close to most estimates of the inimal unemployment rate consistent with stable inflation. In the standard view of the sources of the us external deficlt it sometimes seems as if economists have forgotten about noney and monetary policy. It would be more accurate, however, to say that what proponents of the standard view assume is that monetary policy in each economy is targeted on keeping the economy near what the monetary authority believes is its full-employment level, so that the analysis of fiscal policy can proceed as if the economy were in fact continuously at full employment. This seems to be a reasonable description of the situation in the mid-1980s, though not of the early yerars of the decade. Monetary policy of course could have been different; but to say that "monetary policy failed fully to accommodate fiscal expansion, and therefore the dollar rosen is very far from assigning monetary policy per se an independent role in causing the external inbalances?

\section{Significance of the critique}

The view that monetary policy was responsible for the Us external deficit in the mid-1980s can be rejected as inconsistent with the basic facts. However, this does not demonstrate that fiscal policy did it. There is an important debate over the relationship between the 
budget deficit and saving, and an equally important debate over whether savings rates normally spill over into trade balances. Thus it is important to acknowledge the uncertainites over these links, which have become closely identified with the standard view about the sources of and cure for current account imbalances. However, it is important to notice that eritiques of the fiseal-external linkage have no bearing on the puziling trade developments since 1985. The point is that the US fiscal deficit has not changed mueh since 1985, nor has the US national savings rate. The puzile is how it was possible, given the lack of change in these factors, for the dollar to nove so much -and how it was possible for the dollar to decline so much without much effect on external imbalances.

DO REAL EXCHANGE RATES HAVE TO CHANGE?

We next turn to the key issue of the current debate over the process of international adjustment: the role of real exchange rates in the adjustment process. In the standard view, fiscal imbalances work through the real exchange rate: a budget deficit leads to a real appreciation, which reduces the competitiveness of a country's industry and thus leads to a trade deficit. Us critics of the conventional wistom, however, have argued that no real exchange rate change is necessary, that a shift in savings rates can change the trade balance at constant relative prices. European and Japanese 
commentators often go further, seeming to argue that deficit correction is an alternative to real depreciation, and that the deficit needs to fall in order to keep the dollar from declining further. Thus in a recent article Wakasugi (1987) writes that

The fundamental causes of the dollar's depreciation are the U.S. budget deficit and an unfavorable balance of payants which shows no sign of improving. Only the U.S. itself can recover the dollar's status as an international key currency. Therefore, in the long run, decreasing the budget deficit and enhancing productivity are vital steps.

The fact that the US advocates of the view that real depreciation is unecessary are more or less monetarist in their views on macroeconomic policy, and that their skepticism of the need for real depreciation is tied to a denial of real effects of nominal depreciation, makes it seen to casual observers that this dispute is yet another monetarist-Keynesian argument that hinges on the issue of price flexibility. However, this is a misperception. This is a replay of an old debate, but it is Keynes versus onlin, not Tobin versus Friedman; it is the old question of the relative price effects of an international transfer of resources. see the nature of the issue, it is useful to consider a rudimentary model that reveals the conditions under which a real depreciation is or is not necessary as part of current account adjustment. (A more forma) treatment of this model is given in appendix A). We can then examine the empirical evidence that bears on the question. 
Redistributing expenditure and the real exchange rate

Suppose that the world consists of only two countries, us and ROW. US is assumed initially to be running an undesirable currentaccount deficit. We initially suppose that each of the countries produces only a single good, so that the real exchange rate may be defined as the price of the us good relative to the Row good. Finally, suppose for the sake of argument that both countries are initially at full employment, so that a balance of payments adjustment cannot involve an expansion in either country's output.

Now let us try to reduce us's current account deficit. Can we do this at a constant real exchange rate? It is useful here to write the balance of payments identity in its alternate form

$$
X-M=Y-E
$$

i.e., the external balance is the difference between income and expenditure. Since the real exchange rate is being held constant, we can measure the terms in this equation in terms of either good; more conveniently still, it does no harn to suppose that nominal prices are held constant, so that we can simply measure income and expenditure in nominal terms.

The first point to notice is that there is no channel that links the budget deficit to the trade deficit other than through its effect 
on expenditure. A shift in fiscal policy reduces us expenditure and raises foreign expenditure, and that is all; there is no direct way in which it makes US goods more competitive. The issue, then, is whether it is possible to reduce us expenditure and raise foreign expenditure, while keeping the relative price of the Us and the foreign good constant.

Suppose that through fiscal contraction the US reduces its expenditure by $\$ 100$ billion, while the rest of the world increases its expenditure by the same amount. The fall in US expenditure will directly reduce spending on us goods by $100(1-m)$ billion dollars, where is the fraction of a marginal dollar of Us spending that is spent on imports. On the other hand, the rise in foreign spending will raise spending on US goods by $100 m$ * billion dollars, where m* is the fraction of a marginal dollar of foreign spending that falls on imports. The net change on sepnding on is goods is therefore $100(m+m *-1)$ billion dollars. If $m+n *<1--$ which we will see below is certainsy the case in practice -- then the redistribution of world expenditure will reduce the demand for US goods and increase the demand for foreign goods. To correct t..e excess supply of us goods and the excess demand for ROW goods, the relative price of US goods must fall: the correction of the current account deficit must be effected via a real cepreciation.

The key criterion here is a familiar one: it is the criterion for a terns of trade effect of a transfer. A redistribution of world expenditure must be accompanied by a change in relative prices unless 
the marginal spending pattern of the countries increasing their expenditure is the same as that of the country reducing its spending. If the US has a higher marginal propensity to spend on its own goods than other countries do, which is the case where $+m *<1$, then $a$ 4a!l in the US share of world spending must be accompanied by a fall in the US real exchange rate.

It is important to avoid two confusions that can obscure this point. First is the idea that the issue is sonehow tied to the degree of capital mobility. Ronald Mckinnon has argued strongly that the real exchange rate needs to change to adjust the trade balance only when an economy is "insular", that is, closed to capital movenent. He argues that when capita! is mobile, savings-investment gaps are directly reflected in trade balances, with no need for relative price changes. "With smoothly functioning capital markets, little or no change in the 'rea!' exchange rate is necessary to transfer saving from one country to another".

It should be immediately clear what is wrong with this argument. It confuses the question of whether a change in the savings rate will te reflected in a change in the distribution of world expenditure with the question of whether a change in that distribution necessitates a change in relative prices. The latter question is a question about goods markets, not capital markets. No matter how motile capital may be, if Japanese residents spend much less on US goods at the margin than do US residents, a redistribution of world spending from the US to japan will reduce the demand for US goods at constant relative prices. 
The other confusion that can obseure the issue is to mix wo the necessity for a change in relative prices with the question of whether changes in nomina! exchange rates help produce such changes. If prices are flexible, a currency depreciation by itself has no relative price effects, and a real depreciation can be achieved with a constant nominal exchange rate via deflation in one country and/or inflation in the others. However, this has nothing to do with the question of whether the real exchange rate needs to change.

\section{Empirica! evidence}

We have now seen that external adjustment requires real exchange depreciation to the extent that the marginal propensity to spend on a country's goods is higher for domestic than foreign residents. Casual otservation certainly suggests that this must be the case: average consumption has a very strong domestic bias in every country, so that marginal spending would have to be radically different in order to make $+n *=1$. This conclusion may be confirmed by looking at econometric evidence. Econometric estimates of trade flow equations are not usually presented in this form, but it is possible to recast them in such a way as to yield estimates of and m*. (Appendix $B$ explains how this is oonel. Table 3 presents a number of recent estimates of the demand effects of redistributing world expenditure from the United States to the rest of the world. While there is considerable divergence among estimates, all estimates show $m$ t n* 
much less than one. That is, a fall in US expenditure matched by a rise in rest of world expenditure would represent a net decline in the demand for US goods; a rise in Japanese expenditure matched by a fall in the rest of the world's spending would represent a rise in the demand for Japan's goods.

Consider, for example, the estimate from Krugman and Baldwin 11987), which actually gives the highest estimate of $n$ + n* reported. According to this estinate, a fall of Us expenditure by $\$ 100$ billion would reduce spending on US goods by $\$ 67$ billion, while a corresponding rise in rest-of-world expenditure would provide an offsetting increase in export demand of only $\$ 12$ billion. The remaining $\$ 55$ billion would show up as an excess supply of Us goods, which would have to be eliminated by all in the their relative price.

Why should this be the case? The answer presumably lies in the still highly imperfect integration of narkets for goods and services. Much of the expenditure of even very open economies falls on goods and services that are nontradeable due to perishability or prohibitive transport costs. Trade restrictions turn potentially tradeable goods into de facto nontraded ones. And there are also probably significant Linder effects, in which countries tend even within the set of traded goods to produce goods most suitable for domestic tastes. Thus while it is possible in principle that a redistribution of world expenditure could eliminate a trade deficit wlthout any need for a change in the real exchange rate, the reality of world markets for goods and 
services that are far from perfectly integrated nakes this observation purely acadenic.

\section{Some caveats}

The argument just presented shows that the view that integrated capital markets somehow eliminate the need for real exchange rate adjustaent to accompany a reduction of current account inbalances is misconceived. There is a valid argument that given sufficiently integrated goojs aríkets no real exchange rate changes would be needed, but this argument can be decisively rejected on the basis of both casual observation and econometric evidence. Before closing this discussion, however, it is necessary to tie up sone loose ends.

The first caveat is that even with $m+n *<1$ little real exchange rate change would be necessary if goods produced in different countries were very close substitutes. However, like the alternate argument for a lack of necessity for real exchange rate change, this can be rejected both on the basis of casual observation and on econometric evidence. The casual observation is that the huge swings in real exchange rates since 1980 would have been impossible if goods from different countries were close substitutes. The econometric evidence is that estinated price elasticities in trade are falrly low, typically between 1 and 2 isee Goldstein and Khan 1985, and Brookings 1987). The fall in the relative price of imports to the Us fron 1980 to 1985 provides a natural experiment: although import volume soared, 
the share of imports in GNP actually fell s!ightly, from 11.7 to 11.2 percent; while 1 ags and special factors complicate the picture, this clearly indicates a demand elasticity that cannot be much aore than one.

The second caveat is that countries do not in fact produce only a single good, and relative price changes make take place anong goods that a countey produces. In particular, a reduction in the us current account deficit will to some extent requirea fall in the price of tradeables relative to nontradeables as well as a fall in the price of US exports relative to US imports. Empirical evidence for the US suggests that in the long run the US is more like the one-good economy of our simple model than the "small open econony" whose terns of trade nay be taken as given. However, even if the tradeable-nontradeable price alters significantly in the adjustment process there is no question that a country that reduces its external deficit must reduce its wages relative to those of trading partners. Since many competitiveness indicators focus on unit labor costs rather than export prices, and since the appropriate role of nominal exchange rates may hinge are on wages than on prices (see below), this wage adjustment is important whether or not it is reflected in a change in the teras of trade. 
A more important objection to the view that real depreciation by deficit countries is necessary to reduce imbalances is that the necessity of real depreciation may be avoided if the surplus countries start fron a position of excess capacity. In that case it is possible for expenditure to rise more in the surplus countries than it falls in the deficit country, which could permit a reduction in external deficits without any real depreciation.

A continuation of our numerical illustration may make the point. We previously noted that according to the Krugman-Baldwin estimate a fall in US expenditure by $\$ 100$ billion would reduce spending on US goods by $\$ 67$ billion dollars. Now suppose that instead of rising by only $\$ 100$ billion, expenditure in the rest of the world were to rise by enough so that this reduction in US demand for its own products were offset by export demand. Given an $n *$ of 0.12 , this would require that rest-of-world spending rise by $\$ 558$ billion. Of this spending, $\$ 67$ billion would fall on US goods, exactly offsetting the decline in domestic US demand. The other $\$ 491$ billion would tall on rest-of-world goods, far exceeding the $\$ 33$ billion fall in US import demand.s

This increase in foreign expenditure is possible only if there is enough excess capacity in the rest of the world to accomodate the required increase in production. Specifically, to reduce the us external deficit by $\$ 100$ billion in this way would require that restof-world output $r$ ise by $\$ 458$ billion $<=491$ increase in domestic demand less the 33 fall in US imports). 
If surplus countries have excess capacity, then, it becones possible in principle to reduce the current account deficit without any real depreciation. However, the nunerical example also makes it clear how linited the prospects for doing this are in practice. The income of market econonies outside the US is approximately $\$ 8$ trillion dollars. Thus an increase in output of $\$ 458$ billion would represent a 5.7 percent increase in output. To eliminate the whole 1986 us current account deficit of $\$ 140$ billion at constant relative prices would require an even larger output increase, approxiately 8 percent. Few if any countries believe that they have that ach excess capacity*, and it is hard to believe that the world as a whole outside the US would be willing to risk a demand-led expansion of output of more than, say, two percent. This means that a willingness of surplus countries to risk faster growth can play at best a distinctly secondary role in correcting external imbalances.

In contrast to the debate over whether fiscal policy drives external imbalances, the debate over the role of real exchange rate adjustnent has a clear resolution. Those who deny the need for real exchange rate adjustment are wrong -- many of then wrong at a basic logical level, the rest wrong in their arithaetic. The view that because capital is mobile changes in saving and investment can somehow move the trade balance without moving the real exchange rate is based on a fundamental conceptual confusion, and the case in which this view could turn out to be correct all the same can be decisively rejected 
eapirically. If surplus countries have excess capacity, a willingness on their part to grow faster can substitute for real exchange rate adjustment, but in practice only liajted help can be expected from this source.

There remains, of course, the puzzle of why the real exchange rate changes since 1985 have thus far produced such nodest results. What this discussion shows is that the trade puzzle cannot be resolved by arguing that the savings-investment balance sonehow directly determines the trade balance, without a role for the real exchange rate. There is a real puzzle, but its resolution must be sought in the behavior of markets for goods and services, not in the fact of capital market linkages.

Adjusting external deficits, then, requires real exchange rate adjustment. The remaining question is whether nominal exchange rate changes have a valuable role to play in this process.

THE ROLE OF NGMINAL EXCHANGE RATE ADJUSTMENT

While the key analytical debate about the international adjustment mechanism is probably about the role of the real exchange rate, the immediate policy concern is with nominal exchange rates -whether the dollar should be encouraged or at least allowed to decline further, while the yen rises higher. The idea of prosoting exchange rate movements in pursuit of external balance has come in for 
extremely sharp criticism fron advocates of a return to sone forn of

fixed rates. For example, Mundell' writes that

The clain that [favorable consequences] will follow from depreciation is sheer quackery. It is closer to the truth to say that a policy of appreciating the yen and the European currencies relative to the dollar will cause deflation abroad, inflation at hone, a larger dollar deficit, and vast equity sales to foreign investors. Ownership of factories, technology, and real assets will be exported to finance an even larger trade deficit without there being much, if any real expansion in exports or reduction in the doliar value of inports. US assets will be sold abroad at bargain-basenent prices. If the Anerican dog gets fed better, it will be by eating its own tail.

Is this negative assessment at all justified? To make sense of the dispute, we need to consider two issues. First is the question of whether nominal exchange rate movements are intended to produce real exchange rate changes that would not have happened otherwise, or to facilitate real exchange rate changes driven by other forces. Second is the question of whether it is indeed easier to adjust relative prices via exchange rate changes than via inflation and deflation.

\section{The facilitating role of exchange rate changes}

Suppose that the world economy started from a position of equilibrium, and that a sudden depreciation of the dollar were somehow engineered. Nearly all econonists would agree that in the long run the effect of this depreciation would te some combination of inflation in the US and deflation abroad, with the original real exchange rate 
being eventually restored, and no long run effect on external

balances. To the extent that prices and wages adjust slowly, there would be a temporary period of higher us output and a larger us trade surplus, but few would view this transitory effect as worth seeking through an exogenous depreciation.

Suppose, however, that the world economy does not start froma position of equilibrium. In particular, suppose that an adjustment of US and rest-of-world fiscal policy requires a real us depreciation against the rest of the world. Then the situation is very different. If the dollar does not depreciate, there will have to be some ix of deflation in the US and inflation abroad. To the extent that prices are slow to adjust, this need to change internal price levels will lead both to a delay in the adjustment of external imbalances and a period of unemployment in the US. An exchange rate adjustment can facilitate the process of adjustment by eliminating this need for changes in internal price levels.

The critics of dollar depreciation, such as Mundel!, have portrayed the situation as being our first case, where exchange rate changes are simply imposed on an equilibrium situation. This view in turn gces back to the argument that current account adjustaent does not require any real exchange rate changes. However, we have seen that this argurent is fallacious. There is no reasonable quarrel with the view that narrowing current account divergences does require a fall in the relative prices of goods produced in deficit countries. A depreciation of the dollar and appreciation of the currencies of 
surplus countries looks wuch more favorable when it as viewed, not as an attempt to conjure up a real exchange rate change out of thin air, but as an attenpt to achieve more rapidly and with less cost a

relative price change that would have happened anyway.

While there may be some in the us who expected dollar depreciation to somehow solve the trade problem without any change in domestic expenditure, the standard view has always been clear on this point. The underlying probiem is to narrow the gap between investment and savings; however, dollar depreciation is supposed to facilitate the adjustment of the real exchange rate to its new equilibriun level. To reject this role for the exchange rate out of hand on the grounds that exchange rate changes are neutral in the long run ay not be "sheer quackery", but it is a misrepresentation of a carefully thought-out position.

Now there are some reasonable practical doubts about the current situation: has the exchange rate adjustment that has already taken place been enough? Should exchange rates be encouraged to fall ahead of fiscal policy instead of waiting for fiscal action? We turn briefly to these questions in the last part of the paper. Meanwhile, however, there is the general question of how important it is to adjust nominal exchange rates. If it is almost as easy to change real exchange rates with fixed as with flexible exchange rates, then one might argue against exchange rate adjustment on grounds of monetary stability even if real exchange rates do need to change. 
How useful is exchange rate adjustanent?

Even if prices were perfectly flexible, there would be a good case for preferring exchange rate changes to general deflation in deficit countries and/or inflation in surplus countries. The classie case in defense of using exchange rate adjustment was that of Milton Friedman (1953), who made the analogy with changing to daylight savings time; it is easier to change one price, the exchange rate, than to change the prices of everything an econony produces, just as it is easier for everyone's clocks to be set back an hour than for everyone to change his or her schedule.

However, it is hard to credit the case that prices of goods, and especially wage rates, are so flexible that the huge real exchange rate changes needed to eliminate current external iabalances could have been accomplished quickly through inflation and deflation. The problen is essentially one of coordination within an econony; although the discussion of this problem is faniliar in macroecononics, it is perhaps less tamjliar in the international context, and so will bear Cne more discussion.

Suppose that, as typical estimates suggest, to balance the US current account it was necessary that US wages fall 30 percent relative to forejgn wages fro thejr 1985 peak. For any individual worker a 30 percent wage cut is very drastic; one would inagine that bringing wages down by that much would require a protracted and bitter struggle between employers and employees. However, if all Us wages 
fall by 30 percent, the real wage rate will fall much less, say only 3 percent, since the bulk of US consumption is domestically produced. This means that if all wages could change simultaneously, and each worker could know that other workers would take the same wage cut, it might be possible to get such an adjustment fairly quickly and painlessly. However, this would happen only in a world of hyperrational agents, with no long tern contracts. In the real world nominal wages never fall that much except in the face of a collapsing economy.

What a currency depreciation does is to solve the coordination problem, by lowering all domestic wages relative to foreign wages at the same time. Figure 1 shows the behavior of US unit labor cost relative to its competitors, and of the nominal dollar effective exchange rate, both as calculated by the IMF. The figure surely shows that there is a prima facie case that exchange rate changes do produce short run changes in relative labor cost, and thus can facilitate such a change when one is necessary. The figure also shows the huge magnitude of the fall in US relative wages that has already occurred since the dollar's peak. If one believes that a relative wage change of this magnitude was necessary, it is worth imagining what it would have required to achieve this with a fixed exchange rate.

As years of debate in closed-economy macroeconomics have shown, it is impossible to convince someone committed to the belief that prices are perfectly flexible of the existence of some inertia on the basis of evidence, since evidence can always be rationalized away. 
However, for those less comatted the prospect of attenpting to achieve large real exchange rate movements without changing nominal exchange rates must surely look unappealing.

\section{Exchange rates and capital flows}

A final point that needs to be discussed regarding noninal exchange rate changes is their effect on capital flows. The quotation from Mundell above puts the case in purple prose, but there is fairiy widespread concern among the financial community that a cheap dollar leads to a "sell-off" of Us assets at bargain prices.

The first point to notice about this argument is that it contradicts the basic premise of the critique of nominal depreciation, namely, that it produces only inflation with no real effects. It makes no sense to argue that dollar depreciation cannot do anything to reduce the relative price of US goods and services but that it makes US stocks, capital, and real estate cheap on world arkets -- unless ore has an implicit model in which goods prices and wages are perfectly flexible but asset prices are sticky!

Second, the argument that devaluation leads to excessive selling off of assets to foreigners must be made consistent with the accounting identity that capital inflows have as their counterpart current deficits. If depreciation leads to capital inflows, it must lead to a widened trade deficit -- as Mundell recognizes. However, we have seen that there is no direct channel by which the savings 
investment balance somehow gets translated into the trade balance without affecting the real exchange rate. A foreign transfer of savings to a deficit country aust be associated with a rise in the relative price of that country's goots and services". One doubts whether the clain is actually being made that nominal depreciation leads to real appreciation. In any case, the facts clearly contradict this, since the depreciation of the dollar and the rise of the yen have, as Figure I showed, been associated with approxinately equal real exchange rate changes in the same direction.

CONCLUSIONS AND IMPLICATIONS FOR POLICY

Conelusions

This paper has arrived at one definite conclusion, one strong presumption, and one probability. These are the following:

1. Reducing external imbalances requires real depreciation by deficit countries, real appreciation by surplus countries. The only exception is where there is large excess capacity in the surplus countries, and this caveat is of only modest importance in the current situation. The widespread belief that integrated world capital markets somehow bypass the need for real exchange rate adjustment is a misconception pure and simple. 
2. Nominal exchange rate changes can help facilitate necessary real exchange rate adjustment. One hesitates to say that evidence denonstrates conclusively that prices are inperfectly flexible - there are too many economists committed to undermining such evidence. Nonetheless, it is true. As a practical precautionary stance, in any case, it seems hard to argue with the view that countries should rely on changing currency values rather than deflation and inflation to achieve the real exchange rate changes that are needed to correct external jobalances.

\section{Fiscal imbalances contributed to the widening of external} imba! ances in the 1980s, and fiscal policy can contribute to narrowing these imbalances. As we saw, there are some reasonable grounds for skepticism about the standard view that the US deficit is the root of the whole international imbalance. However, focussing on the us budget deficit remains the best game in town, and it is likely that fiscal correction would make a significant contribution to narrowing current account inbalances.

\section{Inplications for policy}

The purpose of this paper is primarily to discuss how the international adjustment mechanism works, rather than prescribe policy. However, it is important to discuss at least briefly the 
policy implications of this discussion, since it might seem that the paper gives a cliar-cut case for further dollar depreciation and yen appreciation. While a good case can be inade for such a movement, it is worth pointing out several important sources of uncertainty. Cne source of uncertainty is that we do not lknow what the equilibrium pattern of world current account imbalances really is. In particular, there is a reasonable case for arguing that high-saving Japan has a structural current account surplus of $2-3$ percent of GNF that will endure for many years, just as Eritain's 5 percent surplus did for 40 years before World war I. Thus we cannot be sure that the real exchange rate adjustment that would undoubtedly be needed to eliminate Japan's surplus will take place anytime in the foreseeable future.

A second source of uncertainty is the fact that real excharge rates have changed sharply already since the dollar's 1985 peak. Al most surely the current account imbalances of 1986 will narrow over time even at present real exchange rates, as lagged effects work their way through the pipeline. Almost all econometric analyses of the trade position suggest that the real dollar depreciation from 1985 to the sumer of 1987 was still not enough to move the us anywhere close to current account balances, but one cannot definitely rule out the possibility that the econometrics is wrong and that a sharp narrowing of external imbalances is just around the corner.

Finally, to the extent that fiscal adjustment is the fey to correcting the external inbalances, the apparent paralysis of action 
on fiscal policy in the United States and elsewhere poses a problem. There is a reasonatle case thet, given the long 1 ags in the effects of exchange rates on trade, exchange rate adjustment should precede fiscal. change. If fiscal action is still b years away, however, one wold not want to anticipate it with exchange rate adjustinent now. Does this mean that nothing can be said about policy? on the contrary, on the basis of what we do know about the international adjustment. mechamism one quite clear piece of advice can be given: It can be costly to lock nations into potentially unsustainable exchange rates. It is highly likely that when fiscal policy finally is fixed, further real depreciation by the us and further real appreciation by the surplus countries will be required. If polcymakers nonetheless decide that nominal rates should be stabilized at current levels, they should not do so on the basis of a misguided belief that fiscal policy somehow fixes trade imalances without real exchange rate changes. 


\section{Table 1: Savings, Investment, and The External Balance}

1979

1985

\%of GNP:

Gross investment

18.2

16.5

Gross private saving

17.8

17.2

Governaent saving

0.5

$-3.4$

Net foreign investment

0.1

$-2.9$

Real exchange rates

98.9

142.8

Real interest rate

$-1.3$

3.6

IMF index of normalized relative unit labor costs

2 Treasury Bill rate less previous year's CPI increase

Source: Economic Regort of the President, 1987 and IMF International Financial Statisties 


\section{Table 2: Experience since the dollar's peak}

\section{Exchange rate' Real interest Government Net foreign \\ rate ${ }^{2}$ saving investment}

$\begin{array}{lllll}85: 1 & 160 & 7.0 & -96.6 & -83.8 \\ 85: 2 & 156 & 6.3 & -155.6 & -112.0 \\ 85: 3 & 148 & 5.9 & -138.0 & -121.2 \\ 85: 4 & 137 & 5.8 & -155.1 & -143.8 \\ 86: 1 & 129 & 6.0 & -125.1 & -128.6 \\ 86: 2 & 124 & 5.9 & -173.3 & -143.0 \\ 86: 3 & 119 & 5.5 & -133.3 & -148.3 \\ 86: 4 & 118 & 5.0 & -129.4 & -147.7 \\ 87: 1 & 111 & 4.2 & -122.9 & -145.7 \\ \text { IMF MERM index, } 1980=100 & & & \\ 2 \text { Treasury bill rate less previous year's inflation } & \end{array}$

Source: Survey of Current Business and IMF, International Financial Statistics 


\section{Table 3: Estimates of and anplied by some recent studies}

$\begin{array}{lccc}\text { Study } & \text { Inplied } & \text { Inplied } & \text { Sun } \\ \text { Krugman-8aldwin } & .33 & .12 & .45 \\ \text { DRI } & .14 & .05 & .19 \\ \text { NIESR } & .19 & .05 & .23 \\ \text { OECD } & .23 & .05 & .28 \\ \text { EPA } & .24 & .11 & .35 \\ \text { MCM } & .28 & .11 & .39 \\ \text { Taylor } & .33 & .11 & .44 \\ \text { Marris } & .24 & .11 & .35 \\ \text { Source: See Appendix } & 8 & & \end{array}$




\section{Table 4: Derivation of and a}

Elasticity of US Implied $\begin{aligned} & \text { Elasticity of US Implied m* } \\ & \text { import demand }\end{aligned}$
export demand

Expenditure-

based estinates

Krugman-Baddwin

2.9

.33

2.4

.12

DRI

1.2

.14

1.0

.05

NIESR

1.6

.19

1.0

.05

OECD

2.0

.23

1.0

.05

Output-based

estimates

$\begin{array}{lllll}\text { EPA (Japan) } & 1.8 & .24 & 1.2 & .11 \\ \begin{array}{l}\text { MCM (Federal } \\ \text { Reserve Board) }\end{array} & 2.1 & .28 & 2.1 & .11 \\ \text { Tayjor } & 2.5 & .33 & 1.3 & .11 \\ \text { Marris } & 1.8 & .24 & 1.5 & .11\end{array}$

Source: Krugman and Baldwin (1987); Marris (1985); Brookings (1987); and author's calculations. 
NOTES

1. Feldstein's exposition was the one that brought the link between budget and trade deficits to public attention, but this thesis was suggested by many people, so that no one individual can claim sole responsibidity.

2. Which is no doubt why other supply-siders have attacked Roberts' views as "dangerous" and "demand-side in origin". See "Supply-siders suffer a decline in demand for their policy ideas", Wall street Journa!, August $18,1987$.

3. One possible way to expand the role of money is to suppose that the tight US foney of $1980-2$ generated a speculative belief in a permanently strong dollar that the subsequent monetary easing somehow failed to dispel. Although this is a pretty much untestable hypothesis, I have some sympathy with it, since it helps explain both why the dollar rose to levels that were higher than real interest rates could justify (Krugman 1985a) and why so much of the decline in national saving was financed by capital inflows.

4. Mekinnon (1984), P. 14 .

5. In a standard Mundell-fieming model this differential growth with a constant exchange rate could be accomplished through a monetary-fiscal 
$-N_{2}-$

mix. Assune, for example, that the us engages in fiscal contraction while the rest of the world keeps its fiscal policy unchanged. Then the desired combination of foreign growth with constant us output and a stable exchange rate could be achieved by assigning us monetary policy the task of maintaining constant us employment while foreign monetary policy is used to peg the exchange rate. It is straightforward to show that to accomplish these goals the us money supply would have to expand (because world interest rates fall, increasing money demand) but that the rest of the world's money needs to expand by more cbecause it must support not only the increase in demand due to lower interest rates but also an expansion in incomel.

6. The IMF's 1987 World Economic Out look finds that "the degree of Eyclical slack in [the industriald countries is comparatively small at the present time". Japan, France, and the UK are estinated to have negligible ability to expand their economies without generating inflationary pressures; Germany to have only about 3 percentage points of GNP gap. Only Canada and Italy are believed to have excess capacity exceeding 4 percent. (See World Economic Outlook, pp. 57-8,) One may Question these estimates, especially the pessinistic view for Europe. However, for at least the mediun term the crucial point is that policymakers in the major countries are at least this pessinistic, if not more so -- the Germans, for example, do not believe that they have even as much room to expand as the IMF does. Thus the idea that rapid growth in the surplus countries can be expected to do much to close external imbalances is simply unrealistic. 
7. Mundell (1987), p.3.

B. Or a rise in domestic output, if there is excess capacity; but the implicit model of those who deny favorable effects fron devaluation is one in which aonetary shocks cannot induce output expansion.

9. For a recent survey of results, see Bryant and Holthan (1987); also see Krugman and baldwin (1987). There are several ajor sources of uncertainty about how far the dollar would have to fall to achieve current account balance. For one thing, exchange rates have been well away from equilibrium levels for almost the whole of the 1980s, so that it is difficult to disentangle exchange rate effects from other factors, such as changes in the US technological position, the rise of East Asian NICs, or the debt crisis, that might have altered the equilibrium rate. Further, there are some major anomalies in recent betravior, notably in pricing, that suggest scrie kind of structural change and cast doubt on the reliability of all econometric estiates. See in particular Mann (1987). 
REFERENCES

Blanchard, Olivier and Sumaers, Lawrence (1984): "Perspectives on high world real interest rates", Brookings Papers on Econonic Activity $1984: 2$.

Branson, Willian (1985): "Causes of appreciation and volatility of the dollar", in federal Reserve Bank of Kansas City, the US Dollar -Recent Developments, Outlook, and Policy Options.

Brookings institution (1987): "Workshop on the US cuurent-account imbalance: comparative tables and charts", Brookings Discussion Papers in International Economics no. 58.

Bryant, Ralph and Holtham, Gerald (1987): "The external deficit: Why? Where next? What remedy?", Brookings Review, 5, 28-36.

Feldstein, Martin and Horioka, Charles (1980): "Domestic saving and international capital flows", Econonic Journal 90, 314-29.

Frankel, Jeffrey (1986): "International capital mobility and crowdingout in the US economy: Imperfect integration of financial markets or of goods markets?", in R.W. Hafer, ed. "How Open is the US Economy, Lexington, MA: Lexington Books. 
Friedman, Milton (1953): "The case for flexible exchange rates" in

Essays in Positive Econonics, Chicago: University of Chicago Press.

Goldstein, Morris and Khan, Mohsin (1985): "Incone and price effects

in foreign trade", in R. W. Jones and P. B. Kenen, eds., Handbook of

International Economics Ansterdam: Elsevier.

Gordon, Robert (1986): "US fiscal deficits and the world inbalance of Fayments", Hitotsubashi Journal of Economics, $27,7-41$.

Krugman, Paul (1985a): "Is the strong dollar sustainable?", in Federal

Reserve Bank of Kansas City, The US Dollar --Recent Developments,

Outlook, and Policy Options.

Krugman, Paul (1905b): "Fiscal policy, interest rates, and exchange rates: some simple analytics", mineo, MIT.

Krugman, Paul and Baldwin, Richard (1987): "The persistence of the US trade deficit", Brookings Papers on Economic Activity, 1:1987.

Mann, Catherine (1987): "Exchange rates and import prices", presented at NBER Sumrer Institute in International Economics, August 1987.

Marris, Stephen (1985): Deficjts and the Dollar: The World Economy at

Risk, Institute for International Economics Policy study in

International Economics no. 14. 
MeKinnon, Ronald (1984): An international Standard for Monetary

stabilization, Washington: Institute for International Economics.

MeKinnon, Ronald and Ohno, Kenici (1986): "Getting the exchange rate

right: insular versus open economies", presented at American Economic Association meetings, New Orleans, Dec. 1986.

Mundell, Robert (1962): "Capital mobility and stabilization policy

under fixed and flexible exchange rates", Canadian journal of

Economics and Political Science, $29,475-485$.

Mundell, Robert (1987): "A new deal on exchange rates", presented at

the MITl symposiun "The Search for a New Cooperation", Tokyo, January 1987.

Foberts, Paul Craig (1987): "The dollar "erisis' changes its spots", Wall Street Journal, Jan. 23, 1987.

Wakasugi, Ryuhei (1987); "Attack the problen at its source", Look Jagan, July 1987, p.3. 
APPENDIX A: THE TRADE BALANCE AND THE REAL EXCHANGE RATE

In the text the conditions under which a redistribution of world expenditure requires a change in the real exchange rate were explained verbally and through a numerical example. This appendix briefly preserits an algebraic model, first presented in Krugman and Baldwin (1987), that makes the same point in a nore rigorous way.

Consider a world economy consisting of two countries, US and Row. Each country will be assumed to produce a single good that is both consumed dorestically and exported. We let Row's output be numeraire, and define $p$ as the relative price of the US good. Initially let us assume full empleyment, 50 that the US produces a fixed output $y$ and ROW produces a fixed output $y^{*}$. We also leave the deteraination of expenditure in the two countries in the background, simply treating US expenditure in terms of its own good as a parameter, a. For the world as a whole income must equal expenditure. Thus if at is Row expenditure, measured in terms of the ROW good, it must be true that (1) $p a+a *=p y+y *$

or $a *=y *+p(y-a)$

Now it is certainly true as an accounting identity that the trade balance is equal to the excess of incone over expenditure, so that the Us trade balance, in terms of the us good, is simply 
(2) $t=y-a$,

an expression in which the relative price of us goods does not

dipectly appear.

This does not, however, allow us to forget about relative prices.

There is still a requirement that the market for us output clear lin

which case the market for Rol output cleaps as well, by Walras's Law).

Each country will divide its expenditure among the two goods. For

simplicity, let us make the Cobb-Douglas assumption that expenditure

shares are fined, with the US spending a share of its income on

imports and 1 - on domestic output, Rok spending on on imports and 1-

m* on domestic goods. Then we can write the market-clearing condition

as

(3) py $=(1-m) p a+n * 2 *$

or $p[y-(1-n) a]=m * a *$

$=n *[y *+p(y-a)]$

implying

(4) $p=a * y * 10$ 
where $D=(1-n) y-(1-n-n) a$

The implications of this sall model are illustrated in figure 2 , which is much more general than the example. On the horizontal axis is the US level of real expenditurea, while on the vertical axis is the relative price of US output $p$. The line TT is an iso-trade-balance line, that is, it represents a locus of points consistent with some given trade balance in terms of US output. The accounting identity that equates the trade balance to income minus expenditure, regardiess of relative prices, is reflected by the fact that TT is vertical. Meanwhile, the line uU represents points of market-clearing for us output. It is here orawn with a positive slope, which will be the case if $(1-m)>m *$, i.e., Us residents have a higher marginal propensity to spend on US ouput than ROW residents do. Point E is the equilibrium for a given trade balance.

If the picture is as we have drawn it in figure 2 , a reduction in the US trade deficit will necessarily be acconpanied by a decline in the relative price of us ouput. A reduction of us real expenditure shifts TT inward to T'T'; this requires that the equilibriun shift from E to E', which involves a fall in the relative price p. Now there are two circumstances in which this relative price adjustrent need not take place. First is the case where us and ROW goods are perfect substitutes, i.e., we are effectively living ina one-good world. The other is the case where spending patterns are identical between the countries, so that $(1-m)=n *$. In either case, 


$$
-A 4-
$$

the effect is to make UU horizontal (Figure 3), so that a reduction in US expenditure need not be accompanied by a decline in the relative price of what the US produces.

It is also possible for the trade deficit to fall without real depreciation if foreign output expands. Fron (4), an increase in foreign output $y$ will shift UU up, so that if there is excess capacity in ROW it is possible to have a scenario in which us expenditure falls without any real depreciation (Figure 4). 
APPENDIX B: DERIVING ESTIMATES OF M AND M*

The text and Appendix A showed that the need for a real exchange rate change as part of world payments adjustment depends crucially on the fraction of a marginal dollar of expenditure that goes to imports in surplus and deficit countries. Econometric trade flow equations, however, rarely produce results in this form; instead, they yield elasticities of imports with respect to expenditure or more usually income. To extract the key parameters and wa we need to performa transformation on these results.

First consider the case of an estimate of the elasticity of imports with respect to expenditure. Let M denote total imports, $E$ and $Y$ expenditure and income. Then for changes in $E$ we have

$d M=$ mdE or, multiplying and dividing,

$n=(M / E)(d M / M) /(d E / E)$

But $(d M / M) /(d E / E)$ is the elasticity of imports with respect to expenditure; thus may be derived by multiplying an estimate of this elasticity by the share of imports in expenditure.

If the estimated elasticity is instead with respect to income, this poses difficulties of interpretation, since in general there need not be a unique relationship between output and imports even at a constant relative price. In particular, an increase in output to meet 


\section{$8-2$}

increased export deand need not bring with it an increase in inports (except of intermediate goods, which pose a further complication). However, if output fluctuations and changes in domestic expenditure are elosely correlated (as they have usually been), we can view output as a proxy for expenditure. Note that other things equal an increase in domestic expenditure will be reflected in an increase in income:

$d Y=(1-m) d E$

At the same time, it is still true that $d M=$ nde. By substituting out $E$ and rearranging, we eventually arrive at the formula

$=e(M / Y) /[1-(M / Y)]$

where $=(d M / M) /(d Y / Y)$, the elasticity of imports with respect to income.

Table 4 reports elasticities of US exports and imports with respect to expenditure or income from eight recent studies. Six of the studies were presented at a Brookings Workshop on the US current account deficit in January 1987 (Brookings 1987 ); in addition the estimates from Krugman and Baldwin (1987) and Marris (1985) are included.

To convert elasticities into marginal propensities to import, values of $E$ and $Y$ for 1984 were taken for all market economies from the World Bank World Development Report of 1986. Values of M and $M *$ 
B-3

were the 1984 values of imports and exports of goods and services from

the 1987 Economic Report of the President. These were then used, together with estimated elasticities, to construct the table. For

example, Krugaan and Baldwin (1987) estinates a US expenditure

elasticity of import demand of 2.9; since the share of imports in US

expenditure in 1984 was 0.115 , this yields a marginal propensity to import of 0.33 . 


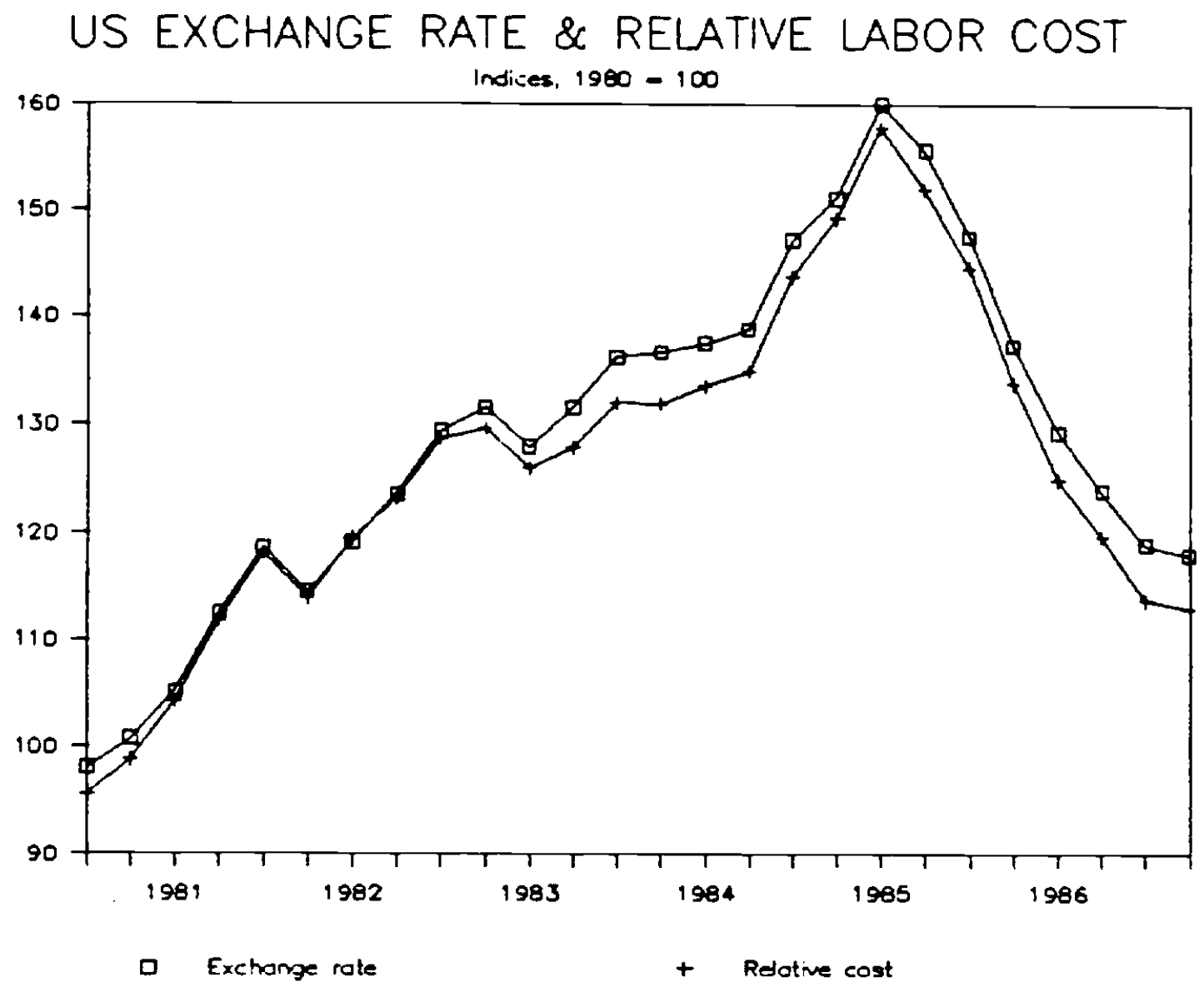

Figure 1 


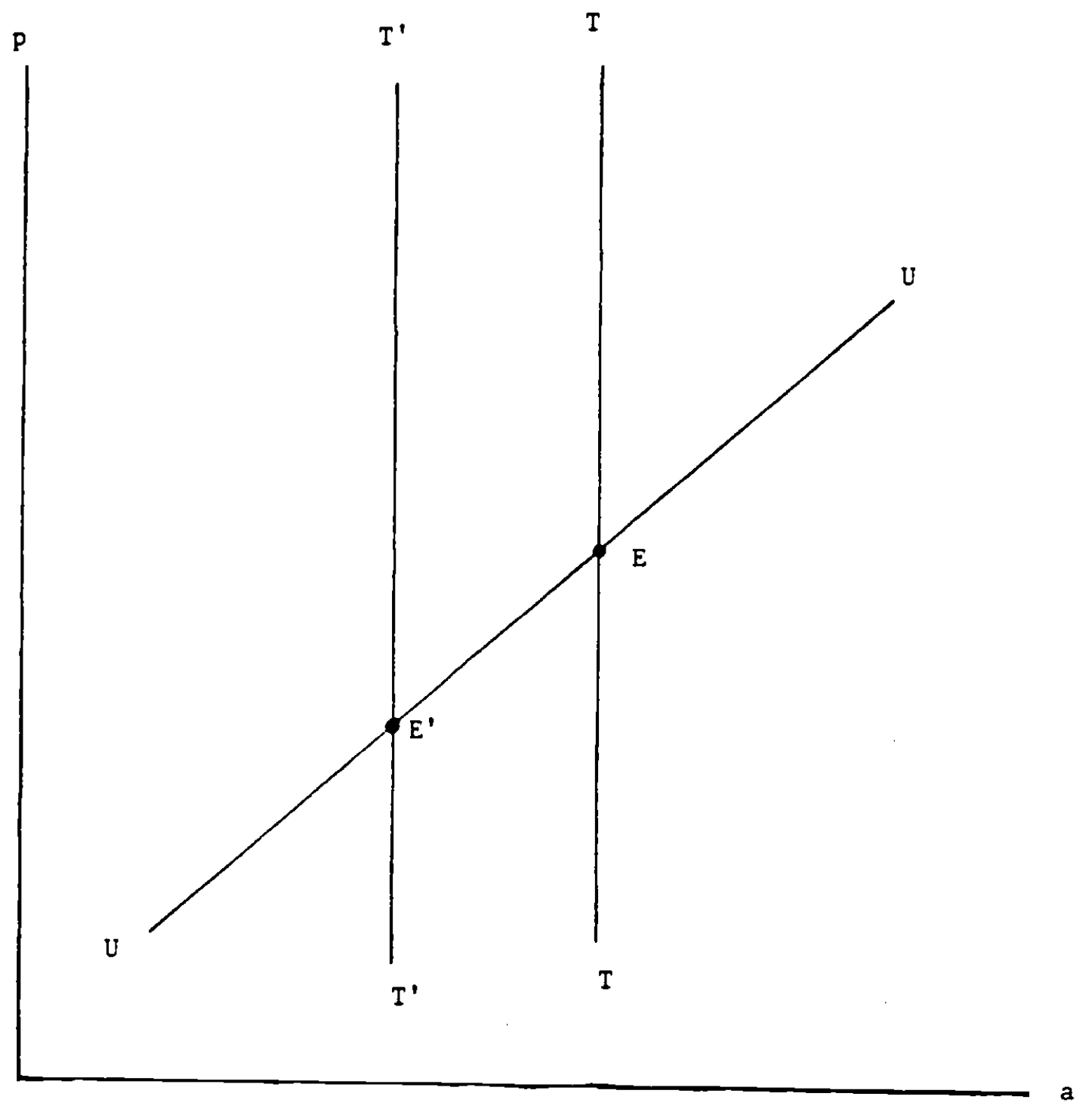

Figure 2 


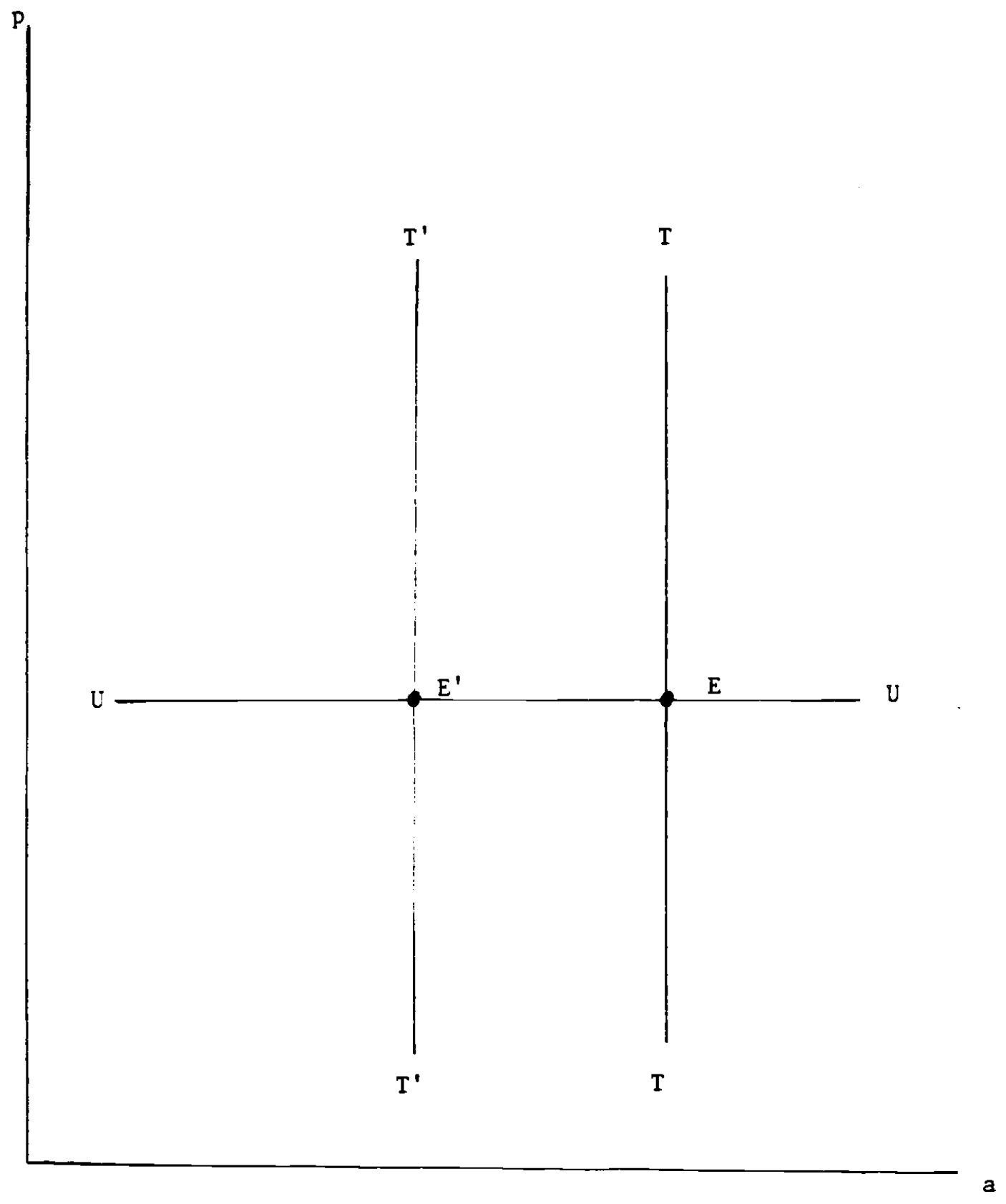

Figure 3 


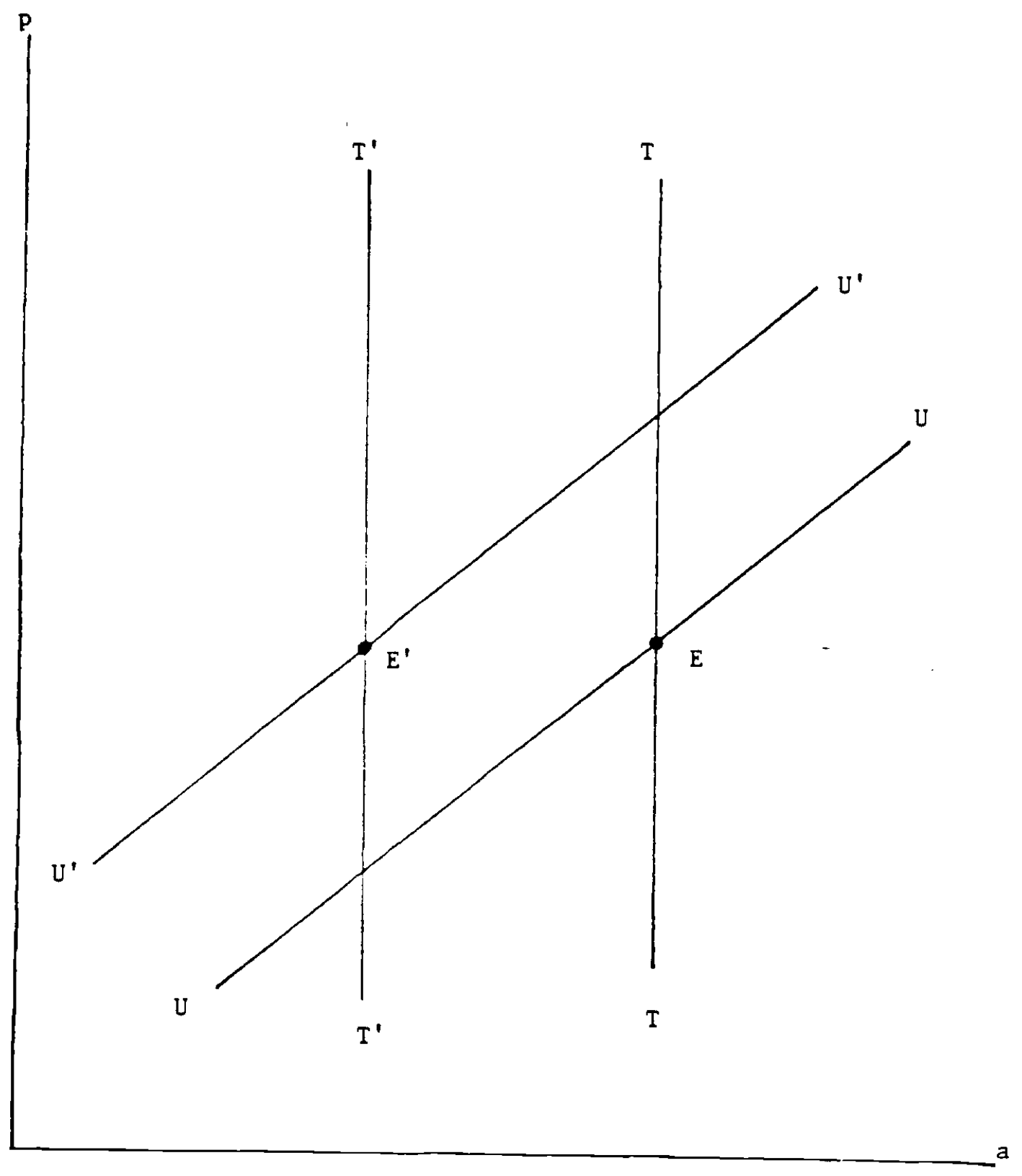

Figure 4 